\title{
Urinary neutral endopeptidase in workers exposed to cadmium: interaction with cigarette smoking
}

Joëlle Nortier, Alfred Bernard, Harry Roels, Monique Deschodt-Lanckman, Christiane Gueuning, Robert Lauwerys

\begin{abstract}
Objectives-Structural impairment of the renal proximal tubular epithelium induced by cadmium (Cd) was investigated by measuring the concentration of neutral endopeptidase 24.11 (NEP), an ectoenzyme of the apical brush border, in the urine of 106 male workers employed in a Cd smelter (among whom 52 were occupationally exposed to $\mathrm{Cd}$ ), and by comparing it with other tubular markers (low molecular weight proteins, lysosomal enzymes).
\end{abstract}

Methods-NEP (EC 3.4.24.11), $\beta-N-$ acetyl-glucosaminidase (NAG) (EC 3.2.1. 30), and NAG-B isoenzyme activities were measured by fluorimetric assays, whereas the concentrations of retinol binding protein (RBP), $\beta_{2}$-microglobulin $\left(\beta_{2} M\right)$, and Clara cell protein (CC16) were measured by automated latex agglutination techniques.

Results-An increased urinary excretion of NEP as well as microproteins was found only in subjects excreting more than $5 \mu \mathrm{g}$ $\mathrm{Cd} / \mathrm{g}$ creatinine. In this group, NEP concentrations were significantly higher in the subjects who smoked. This significant interaction could not be found for any other marker tested.

Conclusions-The data suggest that NEP enzymuria is high even at low exposures to Cd (with a threshold of urinary cadmium excretion (U-Cd) at $5 \mu \mathrm{g} / \mathrm{g}$ creatinine), indicating early structural alterations. Moreover, its particular sensitivity to smoking could be useful in the detection of new population clusters potentially more susceptible to development of nephrotoxic insult.

(Occup Environ Med 1997;54:432-436)

Unité de Toxicologie Industrielle et

Médecine du Travail,

Faculté de Médecine, Université Catholique de Louvain, Brussels,

Belgium

A Bernard

H Roels

R Lauwerys

Correspondence to: Dr Joëlle Nortier,

Laboratoire Pluridisciplinaire de Recherche Expérimentale Biomédicale (LPREB), Campus Erasme CP 603 Route de Lennik 808 , B-1070 Brussels, Belgium.

Accepted 18 December 1996 present in the tubular fluid ${ }^{4}$ An excreted has been identified in human urine and is probably derived from the kidney. ${ }^{5}$ Indeed, the large size of the soluble plasmatic enzyme

Neutral endopeptidase 24.11 (NEP) is a zinc metallopeptidase anchored to the cell surface processes affecting target cell respons cleavage of several peptidic hormones. ${ }^{23}$ In the kidney, this ectoenzyme is abundant on the brush border membranes of the proximal tubular epithelium, processing filtered peptides (about $94 \mathrm{kDa}$ ) and the low concentration of this circulating form (about $13 \mathrm{ng} / \mathrm{ml}$ ) ${ }^{6}$ exclude a significant plasma contribution to the urinary excretion, suggesting that NEP enzymuria is mainly of renal origin. In humans, no data on NEP enzymuria are available, except transiently increased urinary concentrations of NEP early after renal transplantation. ${ }^{7}$ This enhanced enzyme release could be due to the potentially toxic effects of ischaemia or immunosuppressive drugs on the proximal tubular cells.

Numerous studies over the past decades have pointed out the differences in susceptibility to certain nephrotoxicants of several parts of the nephron, according to their distinct morphological, biochemical, and hence, functional properties. This is typically the case for the proximal tubular epithelium and cadmium (Cd). This heavy metal is thought to reach the kidney in the complex Cd-metallothionein (Cd-MT) and accumulates in the renal cortex. ${ }^{8}$ Toxic effects of $\mathrm{Cd}$ on the proximal tubular cell could be exerted by at least two possible steps: firstly, during the ingestion process of the complex Cd-MT from the tubular lumen to the cytoplasm through the apical membrane; and secondly, within the cytosol after dissociation of the complex within the lysosomes. The subsequent cascade of hypothetical mechanisms leads to the occurrence of irreversible changes - that is, tubular proteinuria. ${ }^{9}$ Increased urinary concentrations of low molecular weight microproteins - such as retinol binding protein (RBP), $\beta_{2}$ microglobulin $\left(\beta_{2} M\right)$, and Clara cell protein (CC16) - were found in subjects occupationally exposed to $\mathrm{Cd}$ with urinary $\mathrm{Cd}$ excretion (U-Cd), which reflected the Cd body burden, of around $10 \mu \mathrm{g} \mathrm{Cd} / \mathrm{g}$ creatinine. ${ }^{9}{ }^{10}$

Beside these signs of tubular dysfunction, $\mathrm{Cd}$ can potentially induce structural impairment of the cell. Indeed, an enhanced urinary excretion of intestinal alkaline phosphatase, a brush border enzyme strictly located in the straight segment of the proximal tubule, has been found in moderately exposed workers (U-Cd ranging from 1.5 to $5 \mu \mathrm{g} / \mathrm{g}$ creatinine). ${ }^{11} \mathrm{High}$ urinary concentrations of antigens originating from the apical membrane were also reported at this moderate internal $\mathrm{Cd}$ exposure or at higher exposure intensities (U-Cd $\geqslant \mu \mathrm{g} / \mathrm{g}$ creatinine) ${ }^{12}$ By contrast, in a recent study, no evidence of a threshold was found for the lysosomal isoenzyme $B$ of $\beta-\mathrm{N}$-acetylglucosaminidase enzymuria (NAG-B), suggesting early intracellular alterations at $\mathrm{Cd}$ exposures as low as $2 \mu \mathrm{g} / \mathrm{g}$ creatinine. ${ }^{13}$ 
The aims of the present study were to measure firstly the urinary NEP concentrations in workers occupationally exposed to $\mathrm{Cd}$ and in age matched controls (workers not occupationally exposed to $\mathrm{Cd}$ ). Secondly, we related the NEP enzymuria profile to U-Cd and compared it with other glomerular (albumin and transferrin) and tubular markers (NAG, NAG-B, and microproteins). Finally, a possible effect of tobacco was investigated on all the markers tested.

\section{Materials and methods}

SUBJECTS AND EXPOSURE

The study was conducted on two groups of male workers employed in (or retired from) a $\mathrm{Cd}$ smelter in Belgium. The first group comprised 52 subjects aged 22 to 80 (arithmetic mean (SD) 46.7 (16.7)) and occupationally exposed to Cd. Their geometric mean U-Cd was 2.8 (range $0.4-23.5$ ) $\mu \mathrm{g} / \mathrm{g}$ creatinine and the mean duration of exposure to $\mathrm{Cd}$, estimated by the mean duration of work at job sites in the smelter involving occupational Cd exposure, was 13.6 (range $0.2-42$ ) years.

The second group comprised 54 controls aged 23 to 76 (mean (SD) 46.6 (14.4)) who had no occupational exposure to $\mathrm{Cd}$. Their average U-Cd was 0.63 (range 0.09-6.11) $\mu \mathrm{g} / \mathrm{g}$ creatinine. Some of the control subjects had U-Cd concentrations exceeding the normal range because they were living in the vicinity of the smelter, which is known historically to contaminate the environment with $\mathrm{Cd}{ }^{14}$

As there was overlap between the distributions of U-Cd in occupationally exposed workers and the controls, both groups were redistributed as follows. A control group, in which U-Cd was very low ( $<1 \mu \mathrm{g} / \mathrm{g}$ creatinine), comprised 51 of the control subjects and served as the reference group. Because of their U-Cd, three original controls were excluded and had to be shifted to the exposed group, which finally contained 55 subjects with U-Cd $\geqslant 1 \mu \mathrm{g} / \mathrm{g}$ creatinine.

\section{METHODS}

All subjects provided a spot urine sample which was immediately divided in two aliquots: one stored without additive at $4^{\circ} \mathrm{C}$ for analyses of $\mathrm{Cd}$, creatinine, NEP and NAG, and the other buffered at $\mathrm{pH} 7$ and stored frozen for the assay of RBP, $\beta_{2} M, C C 16$, transferrin, and albumin.

The concentrations of $\mathrm{Cd}$ and creatinine in urine were measured by atomic absorption spectrometry and by the Jaffé reaction, respectively. The creatinine clearance was calculated according to the Cockcroft and Gault formula. ${ }^{15}$

Urinary NEP concentration was measured by a two step spectrofluorimetric assay after $1 / 30$ and $1 / 60$ dilution of the urine samples with $50 \mathrm{mM}$ Tris $\mathrm{HCl}$ buffer $\mathrm{pH} 7.6$, as previously described. ${ }^{7}$ In brief, the synthetic substrate succinyl-alanyl-alanyl-phenylalanine-7amido-4-methyl coumarine (Suc-Ala-Ala-PheAMC) (Bachem, Bubendorf, Switzerland), is cleaved by NEP to produce Phe-AMC. This compound, after incubation with aminopepti- dase $M$ (EC 3.4.11.2) (Pierce, Rockford, Ill, USA), generates AMC. By the use of a standard curve established with purified human renal NEP, it was possible to convert the rate of AMC production into amounts of enzyme. Preliminary experiments were performed with this purified renal enzyme to verify that no interference due to the heavy metal upon NEP activity could render the assay invalid.

The activity of total NAG and that of the B isoenzyme were measured by an automated fluorimetric assay. ${ }^{16}$ The NAG-B isoenzyme was separated from other isoenzymes (mainly the $A$ and $I$ isoenzymes) after fixation of the NAG-A on an anion exchanger as described by Kritz et al. ${ }^{17}$

The concentrations of albumin, transferrin, RBP, $\beta_{2} M$, and CC16 in urine were measured by an automated latex agglutination technique with the antibodies from Dakopatts, Glostrup, Denmark and calibrated with standards of purified proteins. $^{18}$

\section{STATISTICAL ANALYSIS}

Statistical analyses were carried out with the Statview SE graph software. All variables except age were log transformed before statistical analysis and the normality of their distribution was checked with the KolmogoroffSmirnov one sample test. The results were reported as the geometric mean with, when necessary, the range. Groups stratified according to the U-Cd excretion were compared by one way analysis of variance (ANOVA) followed by the Dunnett's multiple comparison test. The level of significance was set at $\mathrm{P}<$ 0.05 .

The interaction between tobacco smoking and exposure to cadmium was assessed by two way ANOVA. A simple regression analysis was used to examine the relations between the urinary excretion of NEP and that of Cd. In the group of smokers, a stepwise regression analysis was carried out to test the influence of the duration of exposure, the current cigarette consumption (cigarettes a day), or the lifetime smoking history (pack-years) on urinary NEP, as well as $\mathrm{U}-\mathrm{Cd}$.

\section{Results}

In the control group, a significant effect of age was found on $\mathrm{U}-\mathrm{Cd}(\mathrm{P}=0.0026)$, urinary NAG excretion ( $P=0.0424)$, serum $\beta_{2} M(P=0.0053)$, and calculated creatinine clearance $(P=0.002)$. According to this, all these variables except $\mathrm{U}-\mathrm{Cd}$ were adjusted for an age value fixed at $\mathbf{4 0}$ years (chosen as it was close to the mean ages of the two studied populations).

After adjustment for age, a dose-effect analysis was performed on all variables by dividing the population exposed to $\mathrm{Cd}(\mathrm{U}-\mathrm{Cd}$ $\geqslant 1 \mu \mathrm{g} / \mathrm{g}$ creatinine) into three groups of increasing U-Cd with thresholds at 2 and 5 $\mu \mathrm{g} / \mathrm{g}$ creatinine. The table shows that signs of proximal tubular impairment judged by increased urinary excretion values of NEP, RBP, $\beta_{2} M$, and CC16, were noted only in the subgroup with $\mathrm{U}-\mathrm{Cd}>5 \mu \mathrm{g} / \mathrm{g}$ creatinine. By contrast, a dose-dependent increase of urinary NAG and NAG-B excretions was found, which 
Table 1 Serum variables and urinary concentration of glomerular and tubular markers in the total population of Cd smelter workers stratified according to the U-Cd

\begin{tabular}{|c|c|c|c|c|}
\hline & \multicolumn{4}{|c|}{$U-C d(\mu g / g$ creatinine $)$} \\
\hline & $<1$ & $1-<2$ & $2-<5$ & $\geqslant 5$ \\
\hline $\mathrm{n}$ & 51 & 18 & 14 & 23 \\
\hline Age (y) & $\begin{array}{l}38.3(10.9) \\
(22-63)\end{array}$ & $\begin{array}{l}48.8^{\star}(14.9) \\
(24-69)\end{array}$ & $\begin{array}{l}52.7^{\star}(16.5) \\
(28-76)\end{array}$ & $\begin{array}{l}59.7^{\star}(13.4) \\
(30-80)\end{array}$ \\
\hline $\mathrm{Cd}(\mu \mathrm{g} / \mathrm{g} \mathrm{cr})$ & $\begin{array}{l}0.55 \\
(0.09-0.98)\end{array}$ & $\begin{array}{l}1.34 \\
(1.04-1.98)\end{array}$ & $\begin{array}{l}3.28^{\star} \\
(2-4.99)\end{array}$ & $\begin{array}{l}8.45^{\star} \\
(5.12-23.5)\end{array}$ \\
\hline $\operatorname{NEP}(\mu \mathrm{g} / \mathrm{g}$ cr $)$ & $\begin{array}{l}42.8 \\
(21-128)\end{array}$ & $\begin{array}{l}52.7 \\
(26-125)\end{array}$ & $\begin{array}{l}49.8 \\
(33-92)\end{array}$ & $\begin{array}{l}75.9^{\star} \\
(35-240)\end{array}$ \\
\hline NAG (UI/g cr) $\dagger$ & $\begin{array}{l}0.63 \\
(0.33-3.87)\end{array}$ & $\begin{array}{l}0.84^{\star} \\
(0.44-2.71)\end{array}$ & $\begin{array}{l}0.84^{\star} \\
(0.42-2.94)\end{array}$ & $\begin{array}{l}1.24^{\star} \\
(0.47-3.04)\end{array}$ \\
\hline NAG-B (UI/g cr) & $\begin{array}{l}0.09 \\
(0.02-0.41)\end{array}$ & $\begin{array}{l}0.14^{\star} \\
(0.06-0.75)\end{array}$ & $\begin{array}{l}0.17^{\star} \\
(0.05-0.43)\end{array}$ & $\begin{array}{l}0.27^{\star} \\
(0.07-1.05)\end{array}$ \\
\hline $\mathrm{CC} 16(\mu \mathrm{g} / \mathrm{g} \mathrm{cr})$ & $\begin{array}{l}16 \\
(3-299)\end{array}$ & $\begin{array}{l}17 \\
(2-246)\end{array}$ & $\begin{array}{l}25 \\
(2-312)\end{array}$ & $\begin{array}{l}124^{\star} \\
(3-2000)\end{array}$ \\
\hline $\mathrm{RBP}(\mu \mathrm{g} / \mathrm{g} \mathrm{cr})$ & $\begin{array}{l}80 \\
(27-217)\end{array}$ & $\begin{array}{l}122 \\
(38-731)\end{array}$ & $\begin{array}{l}132 \\
(49-1150)\end{array}$ & $\begin{array}{l}594^{\star} \\
(12-119000)\end{array}$ \\
\hline$\beta_{2}-M(\mu g / g ~ c r)$ & $\begin{array}{l}73 \\
(23-402)\end{array}$ & $\begin{array}{l}112 \\
(14-938)\end{array}$ & $\begin{array}{l}102 \\
(11-4450)\end{array}$ & $\begin{array}{l}834^{\star} \\
(37-73900)\end{array}$ \\
\hline Transferrin $(\mathrm{mg} / \mathrm{g} \mathrm{cr})$ & $\begin{array}{l}193 \\
(75-3640)\end{array}$ & $\begin{array}{l}284 \\
(72-2120)\end{array}$ & $\begin{array}{l}478^{\star} \\
(78-3460)\end{array}$ & $\begin{array}{l}979^{\star} \\
(129-16700)\end{array}$ \\
\hline Albumin (mg/g cr) & $\begin{array}{l}5.08 \\
(1.24-68.4)\end{array}$ & $\begin{array}{l}7.26 \\
(2.88-60.1)\end{array}$ & $\begin{array}{l}11.2^{\star} \\
(3.17-88.1)\end{array}$ & $\begin{array}{l}15.4^{\star} \\
(2.65-180)\end{array}$ \\
\hline Serum creatinine $(\mathrm{mg} / \mathrm{l})$ & $\begin{array}{l}10.59 \\
(7.19-18.3)\end{array}$ & $\begin{array}{l}10.2 \\
(8.5-14.5)\end{array}$ & $\begin{array}{l}11.6 \\
(8.7-18.7)\end{array}$ & $\begin{array}{l}12.6^{\star} \\
(8.7-28.3)\end{array}$ \\
\hline $\begin{array}{l}\text { Calculated creatinine } \\
\text { clearance }(\mathrm{ml} / \mathrm{min}) \dagger\end{array}$ & $\begin{array}{l}103 \\
(54-143)\end{array}$ & $\begin{array}{l}103 \\
(66-135)\end{array}$ & $\begin{array}{l}90^{\star} \\
(57-145)\end{array}$ & $\begin{array}{l}79^{\star} \\
(33-131)\end{array}$ \\
\hline Serum $\beta_{2}-M(m g / l) \dagger$ & $\begin{array}{l}1.57 \\
(1.15-2.44)\end{array}$ & $\begin{array}{l}1.63 \\
(1.14-3.97)\end{array}$ & $\begin{array}{l}1.70 \\
(1.26-2.81)\end{array}$ & $\begin{array}{l}1.95^{\star} \\
(1.15-3.85)\end{array}$ \\
\hline
\end{tabular}

$\star \mathrm{P}<0.05 v \mathrm{U}-\mathrm{Cd}<1 \mu \mathrm{g} / \mathrm{g}$ creatinine group

tAdjusted for age.

Geometric mean with range except for age (mean (SD)).

was significant even in the group with a U-Cd of 1-2 $\mu \mathrm{g} / \mathrm{g}$ creatinine. Enhanced urinary excretion of albumin and transferrin were also found in the groups with U-Cd of $2-5 \mu \mathrm{g} / \mathrm{g}$ creatinine and $>5 \mu \mathrm{g} / \mathrm{g}$ creatinine. Besides, these groups had a decreased glomerular filtration rate, as estimated by the calculated creatinine clearance and by the concentration of $\beta_{2} \mathrm{M}$ in serum.

We further investigated by two way ANOVA, a possible effect of the smoking habit on the urinary excretion rates of the tubular markers (adjusted for age if necessary). Therefore, each subpopulation was divided into non-smokers,

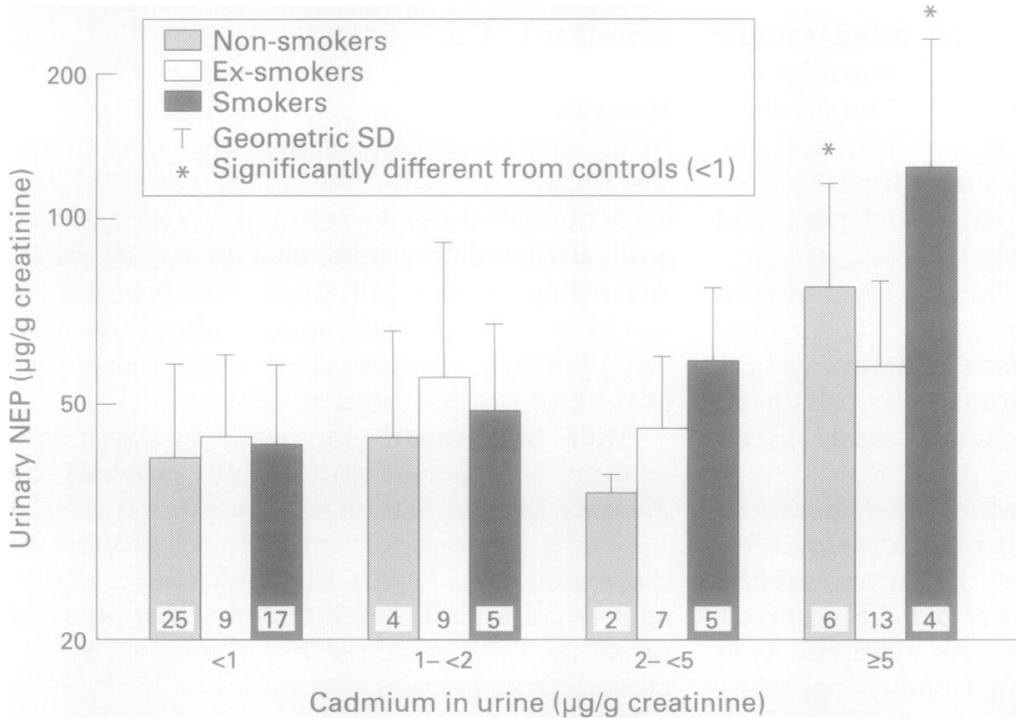

Figure 1 NEP enzymuria in the total population of Cd smelter workers stratified according to the Cd concentration in urine and smoking habit. The number of subjects in each subgroup is noted inside the histograms. Cd effect $P=0.0001$; tobacco effect $P=0.0397$ interaction between $U-C d$ and tobacco $P=0.0324$. ex-smokers (having stopped smoking for one year or more), and active smokers. Figure 1 shows that NEP enzymuria was significantly increased not only in the subgroup of nonsmokers but also in the subgroup of smokers with U-Cd $>5 \mu \mathrm{g} / \mathrm{g}$ creatinine (Cd effect $\mathrm{P}=0.0001$ and tobacco effect $\mathrm{P}=0.0397$ ). A significant interaction on NEP enzymuria was found between $\mathrm{U}-\mathrm{Cd}$ and the smoking habit $(\mathrm{P}=0.0324)$.

The tobacco effect could be illustrated by exploring the relation between U-Cd and urinary NEP concentration in each subpopulation. Figure 2 shows that different slopes were obtained from simple regression analyses, reaching the most significant correlation coefficient in the group of smokers (fig 2C). Among all other tubular markers tested, no effect of tobacco nor interaction between $\mathrm{U}-\mathrm{Cd}$ and smoking was found.

Considering the group of exposed subjects who smoked $(n=14)$, a stepwise regression analysis did not disclose any association between NEP enzymuria and the duration of exposure to $\mathrm{Cd}$, the current smoking habit (cigarettes/day), or the lifetime cigarette consumption (pack-years). The only independent variable emerging as a significant contributor was U-Cd.

\section{Discussion}

Our results provide evidence that, in workers exposed to Cd, renal NEP is released in large amounts into the urine in parallel with increased urinary concentrations of microproteins at the Cd threshold of $5 \mu \mathrm{g} / \mathrm{g}$ creatinine. Despite these similar patterns of urinary excretion, a synergistic effect of U-Cd and tobacco was only found in NEP enzymuria. Our data further suggest that this marker of proximal tubule integrity might be useful in detecting new population clusters potentially more susceptible to development of nephrotoxic insult.

Nephrotoxicity of $\mathrm{Cd}$ has been studied for many years in industrial countries, particularly in Belgium, which is an important producer of this heavy metal in Europe. ${ }^{9}$ The development of accurate detection techniques resulted in a precise measurement of abnormalities in serum and urinary markers associated with respective thresholds of $\mathrm{U}-\mathrm{Cd} .{ }^{12}$ The relation reported at the threshold around $10 \mu \mathrm{g} \mathrm{Cd} / \mathrm{g}$ creatinine between irreversible tubular proteinuria and a faster decline of the renal function with age, led the American Conference of Governmental Industrial Hygienists (ACGIH) to recommend that $5 \mu \mathrm{g} \mathrm{Cd} / \mathrm{g}$ creatinine should be considered as the biological exposure limit for occupational exposure to $\mathrm{Cd} .{ }^{19}{ }^{20}$ Along these lines, a recent European collaborative research project studied the respective pattern of excretion of 26 urinary markers measured in $172 \mathrm{Cd}$ workers stratified according to their U-Cd, focusing on the concept of target nephron segment. ${ }^{21}$ As well as the recognised markers of abnormalities to the glomerular barrier, the combination of two markers that reflect proximal tubular impairment emerged as the hallmark in the early detection of $\mathrm{Cd}$ 

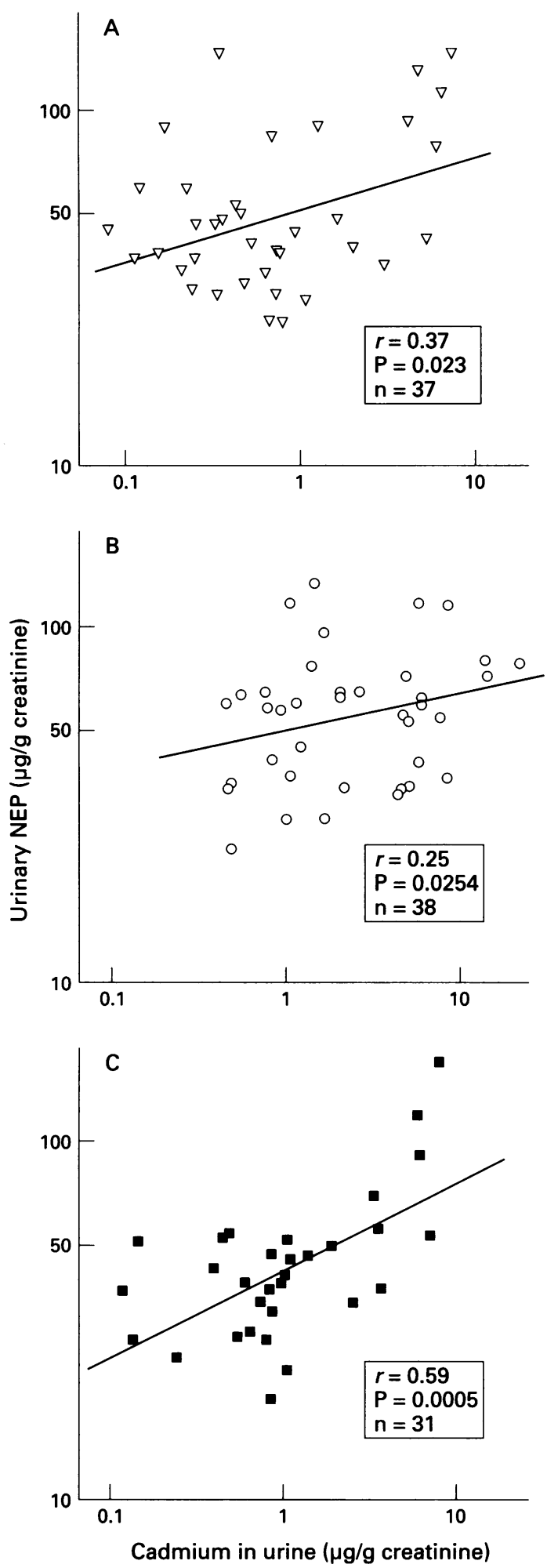

Figure 2 Relation between NEP enzymuria and U-Cd from $C d$ workers subdivided into (A) 37 non-smokers, $(B)$ 38 ex-smokers, and $(C) 31$ smokers.

nephrotoxicity-for example, a microprotein and the intestinal alkaline phosphatase enzymuria.

According to the approach recommended in this multicentre study, ${ }^{21}$ we measured NEP enzymuria in male workers occupationally exposed to $\mathrm{Cd}$ and in age matched controls, and related it to the corresponding concentrations of urinary microproteins . This is, to our knowledge, the first study reporting an abnormal rise in NEP enzymuria in parallel with reabsorptive defects of microproteins. This en- zyme release may actually reflect brush border shedding, increased cellular turnover, or cell death. Experimental data support the first hypothesis, suggesting that $\mathrm{Cd}^{2+}$ could exert toxic cellular effects which result in detachment of apical membrane fragments into the lumen. Indeed, in vitro studies showed that exposure of an established renal proximal epithelial cell line (LLC-PK1 cells) to micromolar concentrations of $\mathrm{Cd}^{2+}$ for several hours caused disruption to the adhering and occluding junctions between the cells. ${ }^{22}$ Moreover, under non-toxic conditions $(1 \mu \mathrm{M} \mathrm{CdCl}), \mathrm{Cd}$ is taken up preferentially from the apical side of the cell by several transport processes mediated by carriers (energy-dependent). ${ }^{23}$ This higher accumulation through the apical membrane may cause interaction with actin cytoskeleton and induce structural alterations in the apical membrane (loss or fusion of microvilli). Such consequences on the proximal tubule as well as on the function of the whole organ (reduction of the glomerular filtration rate) were found in the isolated perfused kidney. ${ }^{24}$

The synergistic effect of U-Cd and tobacco on NEP enzymuria remains to be elucidated. Possible interactions may be hypothesised with the detoxification mechanisms mediated by glutathione within the cell. These defence mechanisms are triggered in eliminating xenobiotics - such as polycyclic hydrocarbons and free radicals derived from a burning cigarette-and rely on the action of two main enzymes: glutathione S-transferase (EC 2.5.1.18.) and glutathione peroxidase (EC 1.11.1.19). ${ }^{25}$ The activity of glutathione peroxidase, a selenium dependent enzyme, is known to be inhibited in vitro by metal ions, mostly by $\mathrm{Cd}^{2+}$ and $\mathrm{Zn}^{2+} \cdot{ }^{26}$ Such an inhibition on both total glutathione S-transferase and glutathione peroxidase activities was shown in vivo by Sidhu et al in rhesus monkeys chronically exposed to $\mathrm{Cd}^{27}$ The inhibition was predominant in the liver and the kidney. Moreover, a recent study of Prozialek and Lamar showed that $\mathrm{Cd}$ induced cytotoxic effects were more severe and rapidly lethal on LLC-PK1 cells previously depleted of glutathione. ${ }^{28}$ Taking into account that glutathione may be a final common detoxification pathway in defending the proximal tubular cell against cigarette derivatives and $\mathrm{Cd}$, it is likely that the association of cigarette smoking and chronic exposure to $\mathrm{Cd}$ could induce cumulative deleterious effects on the cell. Increased NEP enzymuria could then reflect a compromised antioxidant status. Furthermore, it could be suggested that restoration or protection of the glutathione pools might exert some protective effect in this situation of cumulative risk of development of renal dysfunction.

We gratefully acknowledge Mr X Dumont and MrE De Prez for their expert technical assistance. This study was supported by grants from the Fonds de la Recherche Scientifique Médicale (Belgium). AMB is research director and $\mathrm{JN}$ is research assistant of the Fonds National de la Recherche Scientifique (Belgium).

1 Ronco P, Pollard H, Galceran M, Delauche M, Schwartz JC, alloendopeptidase, E.C. 3.4.24.11) in rat organs. Detection using a monoclonal antibody. Lab Invest 1988;58:210-7. 
2 Shipp MA, Look AT. Hematopoietic differentiation antigens that are membrane-associated enzymes: cutting is the key. that are membrane-associt $1993 ; 82: 1052-70$.
Blood

3 Roques BP, Noble F, Daug V, Fournie-Zaluski M-C, BeauRoques BP, Noble F, Daug V, Fournie-Zaluski M-C, Beau-
mont A. Neutral endopeptidase 24.11: structure, inhibimont A. Neutral endopeptidase 24.11: structure, inhibition, and experimental and
col Rev 1993;45:87-146.

4 Schulz WW, Hagler HK, Buja LM, Erdös EG. Ultrastructural localization of angiotensin I- converting enzyme (EC 3.4.15.1) and neutral metalloendo-peptidase (EC 3.4.24.11) in the proximal tubule of the human kidney. $L a b$ Invest 1988;59:789-97.

5 Skidgel RA, Schulz WW, Tam LT, Erdös EG. Human renal angiotensin I converting enzyme and neutral endopeptidase. Kidney Int 1987;31:45-8.

6 Deschodt-Lanckman M, Michaux F, de Prez, Abramowicz D, Vanherweghem J-L, Goldman M. Increased serum levels of endopeptidase 24.11 (enkephalinase) in patients with els of endopeptidase 24.11 (enkephalinase) in pa

7 Nortier J, Abramowicz D, Kinnaert P, Deschodt-Lanckman $M$, Vanherweghem JL. Pathological release of urinary endopeptidase 24.11 early after renal transplantation. Enzyme 1992;46:304-8.

8 Berndt WO. Role of transport in chemically-induced nephrotoxicity. In: Goldberg RS. Mechanisms of injury in renal disease and toxicity. Ann Arbor: CRC Press, 1994:235-46.

9 Bernard AM, Roels HA, Buchet JP, Cardenas A, Lauwerys RR. Cadmium and health: the Belgian experience. In: Nordberg GF, Herber RFM, Alessio L. Cadmium in the human environment: toxicity and carcinogenicity. Lyon: IARC, 1992: 15-33. (IARC Sci Publ No 118.)

10 Lauwerys RR, Bernard AM, Roels HA, Buchet JP Cadmium: exposure markers as predictors of nephrotoxic effects. Clin Chem 1994;40:1391-4.

11 Nouwen EJ, de Broe M. Human intestinal versus tissuenonspecific alkaline phosphatase as complementary urinary markers for the proximal tubule. Kidney Int 1994;46 S43-51.

12 Roels HA, Bernard AM, Cardenas A, Buchet JP, Lauwerys $\mathrm{RR}$, Hotter $\mathrm{G}$, et al. Markers of early renal changes induced by industrial pollutants. III Applications to workers exposed to cadmium. Br 7 Ind Med 1993;50:37-48.

13 Bernard AM, Thielemans N, Roels HA, Lauwerys RR. Association between NAG-B and cadmium in urine with no evidence of a threshold. Occup Environ Med 1995;52. no evidenc.

14 Staessen JA, Lauwerys RR, Ide G, Roels HA, Vincke G, Amery A. Renal function and historical environmental cadmium pollution from zinc smelters. Lancet $1994 ; 343$ 1523-7
15 Cockcroft DW, Gault $\mathrm{MH}$ Prediction of creatinine clearance from serum creatinine. Nephron 1976;16:31-41

16 Tucker SM, Boyd PJR, Thompson AE, Price RG. Automatic assay of $\mathrm{N}$-acetyl- $\beta$-D-glucosaminidase in normal and pathological human urine. Clin Chim Acta 1975;62:333.9.

17 Kritz W, Samaan GJ, Leberre C, Demelier JF, Biou D. Semi-automated fluorimetric assay for total and $\mathrm{B}$

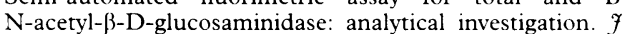
Clin Lab Analysis 1991;5:1-2.

18 Bernard AM, Lauwerys RR. Continuous flow system for the automation of latex immunoassay by particle counting. Clin Chem 1983;29:1007-11.

19 Roels HA, Lauwerys RR, Buchet JP, Bernard AM, Vos A, Overstyns $M$. Health significance of cadmium-induced renal dysfunction: a five-year follow-up. $\mathrm{Br} F \mathrm{Ind} \mathrm{Med}$ 1989;46:755-64

20 American Conference of Governmental Industrial Hygienists. Cadmium, methylisobutylketone and trichloroethylene. Appl Occup Environ Hyg 1991;6:703-10.

21 Fels LM, Bundschuh I, Gwinner W, Jung K, Pergande M, Graubaum HJ, et al. Early urinary markers of target nephron segments as studied in cadmium toxicity. Kidney Int ron segments as
$1994 ; 46: S 81-8$.

22 Prozialek WC, Nieuwenhuis RJ. Cadmium $\left(\mathrm{Cd}^{2+}\right)$ disrupts intercellular junctions and actin filaments in LLC-PK cells. Toxicol Appl Pharmacol 1991;107:81-97.

23 Kimura O, Endo T, Sakata M. Comparison of cadmium uptakes from apical and basolateral membranes of LLC-PK1 cells. Toxicol Appl Pharmacol 1996;137:301-6.

24 Kellerman PS, Clark RAF, Hoilien CA, Linas SL, Molitoris BA. Role of microfilaments in maintenance of proximal tubule structural and functional integrity. $A m \mathscr{f}$ Physiol 1990;259:F279-85.

25 Reed DJ. Glutathione: toxicological implications. Ann Rev Pharmacol Toxicol 1990;30:603-31.

26 Splittgerber AG, Tappel AL. Inhibition of glutathione peroxidase by cadmium and other metal ions. Arch Biochem Biophys 1979;197:534-42.

27 Sidhu M, Sharma M, Bhatia M, Awasthi YC, Nath R Effects of chronic cadmium exposure on glutathione S-transferase and glutathione peroxidase activities in rhesus monkey: the role of selenium. Toxicology 1993;83 203-13.

28 Prozialek WC, Lamar P. Effects of glutathione depletion on the cytotoxic actions of cadmium in LLC-PK1 cells. Toxicol Appl Pharmacol 1995;134:285-95.

\section{Correspondence and editorials}

Occupational and Environmental Medicine welcomes correspondence relating to any of the material appearing in the journal. Results from preliminary or small scale studies may also be published in the correspondence column if this seems appropriate. Letters should be not more than 500 words in length and contain a minimum of references. Tables and figures should be kept to an absolute minimum. Letters are accepted on the understanding that they may be subject to editorial revision and shortening.

The journal also publishes editorials which are normally specially commissioned. The Editor welcomes suggestions regarding suitable topics; those wishing to submit an editorial, however, should do so only after discussion with the Editor. 